\title{
JERUSALEM IN HEBREWS 13:9-14 AND THE DATING OF THE EPISTLE
}

\author{
Peter Walker
}

\begin{abstract}
Summary
In this article it is suggested the author of Hebrews had a developed critique not just of the Temple but also of the city of Jerusalem, and that this is close to the heart of his concerns as expressed in a pivotal passage in 13:9-14. The traces of this theme in earlier chapters are then noted, leading to the conclusion that the author is writing before the Fall of Jerusalem in AD 70 but with a prophetic awareness of what lies in store for the Jewish capital. The consequences of this view for our study of Hebrews and other parts of the New Testament are highlighted in a concluding section.
\end{abstract}

The date of the epistle to the Hebrews continues to be a matter of much debate; is it before or after AD 70? ${ }^{1}$ It will be suggested

\footnotetext{
${ }^{1}$ Advocates of a pre-70 date include: W.L. Lane, Hebrews (2 vols.; Dallas: Word, 1991) lxii-lxvi; B. Lindars, The Theology of the Letter to the Hebrews (Cambridge: CUP, 1991) 10-21; D. Guthrie, Hebrews (Leicester: IVP, 1983) 28-31; P.E. Hughes, A Commentary on the Epistle to the Hebrews (Grand Rapids: Eerdmans, 1977) 30-32; C.F.D. Moule, The Birth of the New Testament (2nd ed.; London: A. \& C. Black, 1966) 44; F.F. Bruce, The Epistle to the Hebrews (London: Marshall, Morgan \& Scott, 1964) xlii-xliv; H. Montefiore, A Commentary on the Epistle to the Hebrews (London: A. \& C. Black, 1964) 9ff.; C. Spicq, L'Epître aux Hébreux (2 vols.; Paris: Gabalda, 1952) 253-261; J.A.T. Robinson, Redating the New Testament (London: SCM Press, 1976) 200-220; see also the commentaries by J. Héring (1970); G.W. Buchanan (1972) and A. Strobel (1975).

Those who prefer a later date include: M.E. Isaacs, Sacred Space: An Approach to the Theology of the Epistle to the Hebrews (JSNT Supp. 73; Sheffield: Sheffield Academic Press, 1992); H. Koester, Introduction to the New Testament (Philadelphia: Fortress Press, 1982) II, 272; W.G. Kümmel, Introduction to the New Testament (London: SCM Press, 1975) 304; A.F.J. Klijn, Der Brief aan de Hebreën (Nijkerk: Callenbach, 1975); R.H. Fuller, A Critical Introduction to the New Testament (London: Duckworth, 1966) 147.
} 
here that a resolution of this issue may be found through noting the presence of an important sub-theme within the epistle-the question of the earthly Jerusalem and its significance.

This theme can be discerned through examining closely a key passage near the end of the letter (13:9-14), but it will also be seen to have been developed in preceding chapters. The implications for dating the epistle will then be noted, concluding with some observations as to the consequences of such a reading for our understanding of Hebrews.

\section{The Theme of Jerusalem in Hebrews 13:9-14}

Do not be carried away by all kinds of strange teachings. It is good for our hearts to be strengthened by grace, not by ceremonial foods [ $\beta \rho \omega \mu \alpha \sigma \nu]$, which are of no value to those who eat them. We have an altar from which those who minister at the tabernacle [ $\sigma \kappa \eta v \hat{n}]$ have no right to eat.

The high priest carries the blood of animals into the Most Holy Place as a sin offering, but the bodies are burned outside the camp. And so Jesus also suffered outside the city gate to make the people holy through his own blood. Let us, then, go to him outside the camp, bearing the disgrace he bore. For here we do not have an enduring city, but we are looking for the city that is to come.

\section{a) The context-Jewish meals}

The precise application of this passage, which has been described as one of the 'most difficult passages of the entire New Testament' 2 depends chiefly on our interpretation of the word $\beta \rho \hat{\omega} \mu \alpha$. What precisely is being denounced?

Scholars such as Lindars and Lane rightly argue that the Jewish context of vv. 10-12 (in which the author gives his reason for this stipulation) suggests that the 'foods' in question must have been Jewish (festival?) meals which drew some of their significance from their dependency upon the Temple cult. ${ }^{3}$ They conclude that the author's point is that involvement

${ }^{2}$ H. Koester, '“Outside the Camp": Hebrews 13:9-14', HTR 55 (1962) 299.

'Lindars, op. cit., 10: 'The reference is probably to synagogue meals, held especially at festival times to give the worshippers a stronger sense of 
in such Jewish meals necessarily involves an affirmation of the validity of the Temple-which runs contrary to his contention that Christ's sacrificial death should be seen as the fulfilment of the Day of Atonement rituals associated with the Temple. 4

If correct, this is highly significant. For it is the first (and only) time that the author indicates to his readers how his arguments concerning Christ's sacrificial death will affect in practice their approach to the Jerusalem Temple.

\section{b) The call-to choose}

Summing up his lengthy argument the author asserts that his readers now 'have an altar' (v. 10) which is quite different from that within the Jewish Temple. Strictly, it is not a physical one, though it is based on physical events-namely the sacrificial death of Jesus. ${ }^{5}$ Yet the physical aspect of the word 'altar' suits his purpose now, for he wants to show that his earlier theological argumentation concerning Christ's sacrifice does have practical consequences for the contemporary Jewish 'altar' in the Temple: as far as Christians are concerned it is now redundant inasmuch as they have in Christ an 'altar' that can

solidarity with the worship of the temple in Jerusalem. This does not mean meals directly associated with atonement sacrifices, but meals which strengthen the sense of solidarity with the temple where the whole sacrificial system is performed on behalf of Jews everywhere.' $C f$. also Lane, op. cit., 530-536; B.F. Westcott, The Epistle to the Hebrews (3rd. ed.; London: Macmillan, 1903) 436; Hughes, op. cit., 572-74; Buchanan, op. cit., 233. Unfortunately little evidence survives of the exact nature of such meals in the Diaspora.

4Thus, though the word 'ceremonial' (in NIV) is strictly an addition to the text, it brings out the sense that this was no ordinary 'food' but food eaten within a specifically religious context. Yet the word 'ceremonial' must not be pushed too far; as Lane observes, 'it is unnecessary to distinguish sharply between ordinary Jewish meals and special cultic meal times. Every Jewish meal possessed a cultic character' (op. cit., 534). Nor is the author concerned with the external aspect of 'ceremonial'; his criticism is due to the integral connection between these meals and the Temple cult.

5Isaacs, op. cit., 216: 'the altar is located neither in heaven, nor on earth at the Eucharist, but represents the sacrifice of Jesus'. The author's choice of words here is skilful: by combining the notions of the 'altar' (a physical term) and the 'tabernacle' (a more theological term) he shows that his argument is theological in essence but not merely theoretical in its consequences. 
offer them the reality and not just the 'shadow'. Despite the great value of the Temple within Judaism, the author was effectively calling these Jewish Christians to make a choice and to deny the value of the Temple in the light of Christ's death.

In so doing he was actually calling them to forego their Jewish roots, and for Jesus' sake to 'leave the camp' of Judaism. ${ }^{6}$ Moreover, in describing such food ( $\left.\beta \rho \hat{\omega} \mu \alpha\right)$ as having 'no value' and saying that 'those who minister at the tabernacle have no right', he effectively denounces the value of such Jewish meals and draws lines between these two religious systems which appear mutually exclusive. ${ }^{7}$ For a Christian of Jewish background, as the author of Hebrews evidently was, this clear-cut position which sees no room for compromise between his new faith and the Judaism of his upbringing is quite remarkable.

Hebrews' portrayal of Jesus as the 'true High Priest' had inevitably drawn a contrast between the earthly Temple system and the new Christian dispensation. In those earlier chapters Hebrews had needed to speak both positively and negatively about the Temple, on the one hand affirming it as providing the God-given means of atonement under the Old Covenant, whilst at the same time pointing to its inadequacies when seen in the greater light of Christ. It was a necessary 'type' on earth of the heavenly reality which had now been revealed in Christ. In so doing the relationship between Christ and the Temple had been portrayed in vertical terms, with the earthly 'tabernacle' being seen as having a positive role of pointing upwards to the heavenly one. What is new now in chapter 13 is that (by drawing on the historical and geographical aspects of the crucifixion) the relationship between Jesus and the Temple is now portrayed horizontally. Jesus' death takes

${ }^{6}$ The irony of this can be noted in his terming the active promotion of such Jewish meals as a form of 'strange teaching' ( $\delta\llcorner\delta \alpha \chi \alpha i \varsigma . . . \xi \xi \dot{\varepsilon} v \alpha l \zeta$, v. 9). Yet for Christians of Jewish background such meals would have been very familiar-far from 'strange'! In so describing them he asserts that they are 'strange' to the unerring truth of Jesus (v. 8), thereby indicating the radical contrast which for him now exists between the two religious systems.

7It is possible that this strong and divisive language is itself a retort to Jewish claims that Christians had 'no right' to participate in their worship. 
place 'outside the city gate' (v. 12) in a different location to that of the 'Most Holy Place' (v. 11). As a result the reader is presented in a new way with the need to make a choice: is one to 'go to Jesus outside the camp' (v. 13) or remain, as it were, within the city and focused on the Temple? To use alternative 'geographical' language: are one's loyalties with the Temple mount or with 'the place of the skull'? The contrast between the two is now made plain and whilst it is affirmed that the Temple had truly possessed a divine status in former times this is now denied to it because of Christ's coming. The 'sign' needs to give way in the presence of the 'thing signified'.

The author is therefore drawing upon the full scope of his earlier argument in order to conclude with some specific practical applications. Throughout his sermon he had argued that Christ's death was an integral part of his work as the 'true High Priest'. Now, however, he invites his readers to be less abstract and to consider in their mind's eye the sombre realities of the crucifixion narrative itself; thereby they are enabled to see the powerful truth that Jesus, rejected from the city of Jerusalem, was yet in a most unexpected and (at the time) unnoticed way truly enacting the ritual of the Day of Atonement which year by year was enacted within the Temple precincts but half a mile away from Golgotha. Jesus, though tried before Caiaphas on a charge of blasphemy, was in fact through that death about to fulfil the high priest's most significant role. The distinct impression we receive is that we now have a straightforward choice: which high priest will we follow?

The central thrust of Hebrews would therefore appear to be not just a 'call to commitment' but also and more profoundly a call to make a choice. ${ }^{8}$ The readers are presented with a choice of 'altar' and a choice of 'high priest'. Yet, the author insists, there are further choices to be made. Jesus stands 'outside the camp' (v. 13). What did he mean in calling his readers to 'leave the camp'?

8See Lane's shorter exposition of the letter: Hebrews: A Call to Commitment (Peabody: Hendrickson, 1985). 
His use of 'camp' ( $\pi \alpha \rho \varepsilon \mu \beta о \lambda \eta$ ') naturally fits in with the portrayal of Israel in the wilderness-seen most clearly in his consistent use of the word 'tabernacle'. ${ }^{9}$ Its use here is quite subtle since it inevitably includes both a geographical and a personal sense. At one level it speaks of Israel-the people of God who dwelt in the camp. Yet in another sense (especially in v. 13 where the phrase 'outside the camp' clearly echoes the language in v. 12 of Jesus' suffering 'outside the gate') it cannot avoid having a reference to the city of Jerusalem. ${ }^{10}$

The use of 'camp' in these verses thus becomes a skilful means of widening the focus of the critique. So much of the author's argumentation had focused exclusively on the Temple; now it becomes clear that the entities of Jerusalem and Judaism-which focus on the Temple in the same way as the 'camp' once surrounded the 'tabernacle' - have also been radically affected by the coming of Christ.

In calling his audience to 'go outside the camp', therefore, he is challenging them to forego both a people and a place, both Judaism and Jerusalem. ${ }^{11}$ Despite the difficulty of this for people of Jewish stock and the evident stigma ('disgrace', v. 13) which it will incur from their Jewish contemporaries, it is this to which Jesus calls them. In v. 13 it is as though Jesus were beckoning to the readers from Golgotha, inviting them not to be afraid to follow in his steps but rather to 'take up their cross and follow him' (cf. Mark 8:34).

The challenge in these verses to make a break of some kind with Judaism has often been highlighted and we shall

\footnotetext{
${ }^{9}$ An explanation of this stylised picture of Israel is offered below in III (c). ${ }^{10}$ This might reflect some contemporary ways at Qumran of describing Jerusalem in 4QMMT: "We reckon the Temple is "the Tent of witness", while Jerusalem is the "camp". "Outside the camp" means "outside" Jerusalem...One is not to bring dogs into the holy "camp" because they eat some of the bones in the Temple while the flesh is still on them, because Jerusalem is the holy "camp" - the place that He chose from among all the tribes of Israel. Thus Jerusalem is the foremost of the "camps of Israel"' (as translated in R.H. Eisenman and M. Wise, The Dead Sea Scrolls Uncovered (Shaftesbury: Element, 1992) 194-5.

${ }^{11}$ This interpretation would seem to make better sense of the Jewish context than, for example, Koester's suggestion that the call is to leave the 'sacred' world for the 'non-sacred' (art. cit., 315).
} 
discuss briefly its significance below. ${ }^{12}$ The challenge to 'leave the camp' in the sense of Jerusalem, however, does not appear to have been noted. To this we now turn.

\section{c) The Critique-of Jerusalem}

The author's reference to the crucifixion narrative forces his readers to consider the theological implications of Jesus' death against the backdrop of the physical city of Jerusalem. When he encourages them to 'leave the camp' this is indeed figurative language, but it depends for its power on the fact that this is what Jesus did in concrete reality when he was led out from Jerusalem to Golgotha. The author did not use the phrase 'leave the city' because he needed to say more than that, but his choice of 'camp' cannot be interpreted in such a way that a reference to the city of Jerusalem is totally excluded. Any doubts on this score are removed by noting how in the next verse (v. 14) he proceeds to talk immediately about the 'city'; the 'city-concept' is evidently on his mind. 13

In these verses, therefore, the author is offering a new evaluation of Jerusalem in the light of Jesus' death; his call to 'leave the camp' means that his readers must break with their Jewish contemporaries on this central issue as well. He gives them three different reasons.

First, since Jerusalem's religious significance was integrally connected to the Temple, then it follows that his contention that Christians have a new 'altar' must have repercussions for the city as well. If the 'Most Holy Place' has now been rendered redundant, the holiness of the 'holy city' built around it must also be brought into question.

Secondly, radical implications for the 'holiness' of Jerusalem and the Temple must flow out from the assertion in vv. 11-12 that Jesus' death fulfils the pattern of the Atonement ritual. In v. 11 he makes the point that the carcasses of the sacrificial animals were not taken into the 'Most Holy Place' but rather ejected and burned 'outside the camp'. The biblical

\footnotetext{
12See below IV (a).

${ }^{13}$ Contra e.g. R.M. Wilson's comment on this verse in Hebrews (Basingstoke: Marshall, Morgan and Scott, 1987) 244: 'there is no need to think of Jerusalem'.
} 
tradition makes it clear that this place for the disposal of such carcasses was polluted or 'unholy' ${ }^{14}$ Yet now Jesus too has been dismissed from the holy enclosure and sent, as it were, to this 'place of unholiness'; however, in that very place he has done the great act which alone can 'make the people holy through his own blood' (v. 12). Paradoxically, therefore, the 'unholy place' has now in God's purposes become the source of the only true holiness.

This must have repercussions for the city of Jerusalem. For, as F.F. Bruce says when commenting on this verse,

In Jesus the old values had been reversed. What was formerly sacred was now unhallowed, because Jesus had been expelled from it; what was formerly unhallowed was now sacred, because Jesus was there. ${ }^{15}$

Since it was Jerusalem, and not the Temple, from which Jesus was 'expelled', it follows (if Bruce is correct) that it is the city which is now 'unhallowed'. The city's claim to holiness could thus never be the same again, for Jesus' death had desecrated it. Just as the 'stone that was rejected' had become the chief corner-stone' (Mk. 12:10) so God had vindicated the Jesus

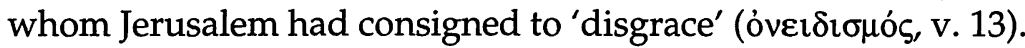
Given these suggestive ideas, it is not hard to draw out the negative corollaries for Jerusalem to which the author was leading. It would have been offensive indeed to state explicitly that the Temple and city had been desecrated and pollutedtaking on the role of the carcass-dump-yet the implicit consequences of his picture were not hard to infer.

- Thirdly, focusing spiritually on Jerusalem is to be avoided because 'here we do not have an enduring city' (v. 13). Wrenched from its context this verse can easily be interpreted in very general or even Platonic terms as teaching the 'other-

${ }^{14}$ See Lv. 16:26-8; cf. e.g. Dt. 23:9-14. On first-century Jewish practice see e.g. E. Martin, Secrets of Golgotha: the Forgotten History of Christ's Crucifixion (Alhambra, CA: ASK, 1988).

15F.F. Bruce, op. cit., 403. 
worldly' focus of Christian spirituality. ${ }^{16}$ In context, however, and especially given the Jewish background of the readers, the resonance concerning Jerusalem cannot be avoided. The author was drawing them away from a religious interest in Jerusalem by alerting them to the impermanent (ov $\mu \varepsilon \dot{v} v v \sigma \alpha v$ ) and transient nature of that city. As an object of religious hope it will disappoint them; not so 'the city that is to come'. This transient, earthly city was not to be part of their fundamental identity.

Putting these arguments together a powerful picture emerges. The Temple at the heart of the city is defunct; the city itself through Jesus' death has been defiled; the earthly Jerusalem in comparison with the heavenly has been diminished.

The author is thus drawing out negative, pragmatic consequences from truths which earlier were introduced in a positive context. In both the previous chapters there had been references to the 'city built by God' / the 'heavenly Jerusalem' $(11: 10,16 ; 12: 22)$, yet what this meant for the earthly Jerusalem was not indicated at the time. Now it is. 'The city that is to come' forces an inevitable contrast with the earthly Jerusalem which can now be seen to be 'no enduring city'. Indeed in the imagery of 12:27-8 the earthly Jerusalem is now seen as belonging to the 'things that can be shaken'; by contrast the 'city that is to come' is part of the 'kingdom that cannot be shaken'. Such ideas, though a natural part of the overall eschatological focus of Hebrews, also reflect an evaluation of Jerusalem. Reflecting on the death of Jesus 'outside the gate' of the city, the author realises that Jerusalem can never again play the pivotal role within God's purposes that it once had.

The author is thus presenting to his readers an implicit critique of Jerusalem and its significance. He is indicating that the religious affection which as native Jews they naturally feel towards that mother-city is part of that which they have to surrender if they are to follow in the steps of the crucified

16This 'Platonic' reading of Hebrews is seen especially in J.W. Thompson, The Beginnings of Christian Philosophy: The Epistle to the Hebrews (CBQMS 13; Washington: Cath. Bib. Assoc. of America, 1981). 
Jesus. ${ }^{17}$ Unless they are themselves resident in Jerusalem (which is unlikely), ${ }^{18}$ they cannot literally 'leave the city', but in this spiritual sense they can, and they must. 19

Intriguingly this means that, if his readers are to attain to the 'heavenly Jerusalem' they must first 'leave' or discard the earthly Jerusalem. In this 'tale of two cities' a choice is required. Far from the earthly Jerusalem being a means to the heavenly city (as commonly assumed in Jewish thinking), 20 it is now an obstacle; now that the 'heavenly Jerusalem' has been revealed (12:22-24) the earthly sign has become a barrier.

More striking still, the new starting-point for the journey to the 'heavenly Jerusalem' is instead the shameful place where Jesus 'suffered' (v. 12). In calling his readers to 'go out to him outside the camp' (v. 13) the author is effectively portraying Jesus as still located on the cross; yet in the previous chapter Jesus had been portrayed as awaiting his followers in the 'heavenly Jerusalem' (12:24). By means of this powerful superimposition of ideas (suggesting that Jesus is simultaneously at both Golgotha and in the 'heavenly Jerusalem') he is able to teach that the way to the latter is only through the former, that the route to glory begins in shame ( $c f .12: 2)$, and that Golgotha is the surprising gateway into heaven. Because Jesus was rejected at the cross but then vindicated in 'heaven', his followers must follow a similar path-which demands both endurance in the face of 'disgrace' and faith in the hope of future vindication.

${ }^{17}$ For first-century Jewish attitudes to Jerusalem see e.g. Philo, Legatio, 281: 'while she is my native city, she is not only the mother city of the land of Judaea, but also of many other countries'. See further, S. Safrai, 'Relations between the Diaspora and the Land of Israel' in S. Safrai and M. Stern (eds.), Compendia Rerum Iudaicarum ad Novum Testamentum (Assen: Van Gorcum, 1974) I, 184-215.

${ }^{18}$ See further below at $\mathrm{n} .52$.

${ }^{19} \mathrm{Cf}$. J.D.G. Dunn, The Partings of the Ways (London: SCM Press, 1991) 90f.: There is a 'deep sense of alienation from the present Jerusalem. Discipleship of Jesus means going 'outside the camp'; looking for the heavenly city to come means also looking away from the earthly Jerusalem'.

${ }^{20}$ E.g. R. Yohanan in Ta'anit 5a: 'The holy One blessed be He said, "I will not enter celestial Jerusalem until I enter terrestrial Jerusalem"'. 
Inevitably such a renunciation of Jerusalem would be interpreted by fellow-Jews as a denial of their Jewish heritage; this 'leaving of the camp' of Jerusalem in a spiritual sense would lead inevitably to an actual 'leaving of the camp' of Judaism. This would then entail their experiencing something of the 'disgrace' that Jesus himself experienced when rejected by Jerusalem. Yet this is precisely what the author means when he issues his challenging call to 'go to him outside the camp'.

\section{d) Conclusion}

It is a startling contrast. In the light of the previous arguments the readers might have expected a contrast between Jesus and the Temple, but they are now presented also with this contrast between Jesus and Jerusalem. Yet it is more even than that. In locating Jesus 'outside the camp' the author is highlighting the contrast between Jesus and Judaism itself; he is effectively placing Jesus outside the boundaries of the 'Jewish camp'. This is remarkable enough as the opinion of a Jewish writer concerning his current perception of the relations between the two religious groupings. ${ }^{21}$ Yet it is even more remarkable for the fact that he superimposes this current state of affairs backwards onto the historical narrative of the crucifixion, thereby implying that this painful division (between Jews who believed in Jesus and those who did not) was written into the programme from the outset. Jerusalem's treatment of Jesus, he intimates, should have been a clear indication of how a Judaism centred on Jerusalem would thereafter treat Jesus' followers. In his crucifixion he was ostracised from 'the camp'; so will his disciples be. 22

${ }^{21} C f$. Dunn, op. cit., 91: 'we find a clear sense of a decisive breach with what had gone before...For Hebrews and a Judaism still focussed on the Temple the ways had parted'.

22If such a reading appears stark or hostile it can be observed that Jesus' death is described in this passage as being in order to sanctify 'the people' ( $\tau$ òv $\lambda \alpha$ óv, v. 12) i.e. the people of the city; thus, while the 'camp' may be defiled, there is nothing to stop individuals within it from discovering the new holiness available through Jesus' death. The institution is criticised but the door is held open to individuals within it. Moreover, in speaking for simplicity's sake of the contrast between 'Judaism and Christianity' there is the danger of retrospective anachronism; the author himself 
The theme of Jerusalem is thus an integral part of the author's concern and takes us to the heart of the appeal which he makes to the readers in this important final chapter. ${ }^{23}$

\section{Jerusalem and the Land in earlier chapters}

If in Hebrews 13:9-14 there is indeed this critique of Jerusalem and not just of the Temple, it is legitimate to ask if there are any indications of this critique to be seen in earlier chapters.

There is also the question of the Land. In Judaism Temple, city and Land formed a triad of significant geographical realia; they were like concentric circles, integrally linked together. ${ }^{24}$ Hence a person who saw that the status of the Temple had been affected by Christ's death, would also view the city and the Land in a new way; for in many ways they depended on that Temple for their significance. A critique of the Temple would probably imply a critique of them as well.

\section{a) The Promised Land}

Viewed in this light the several passages in Hebrews which relate to the Land (chs. 3, 4 and 11) merit further investigation.

Hebrews 3:1-4:13 reveals some significant assumptions concerning the Land. The force of the argument depends upon God's warning in Psalm 95:8 (that the rebellious Israelites would 'never enter my rest') being seen as potentially applicable to his readers as well. This in turn requires that this divine 'rest', which in its original context had had a primary reference to the entrance into the 'promised land', must be understood rather as a reference to eschatological salvation in 'heaven'. Of necessity this entails the further conviction that the entrance

would more probably have spoken instead of two forms of Judaism, yet his own argument reveals the extent of the division between them.

${ }^{23}$ This confirms the argument that ch. 13 is an integral part of the epistle: see F.V. Filson in 'Yesterday': A study of Hebrews in the light of chapter 13 (SBT 2nd. ser. 4; Naperville: Allenson, 1976). Indeed ch. 13 proves to be essential, being the place where in a more 'pastoral' context the author can apply his theological argument to the practical concerns of his readers.

${ }^{24}$ As argued by e.g. N.T. Wright in P.W.L. Walker (ed.), Jerusalem Past and Present in the Purposes of God (Cambridge: Tyndale, 1992) 70. 
into the promised Land under Joshua was not really the 'rest' which God had promised, being at best a pointer to that greater, heavenly reality. In vv. 8-9, where these ideas come to the fore, the author goes even further, denying that the historical entrance into the promised Land gave the people 'rest' at all:

For if Joshua had given them rest, God would not have spoken later about another day. There remains, then, a Sabbath-rest for the people of God.

What would be the consequences of such a view for the author's understanding of the contemporary Land? For in effect he is asserting that the whole concept of the 'promised land' must be seen as an advance metaphor for the heavenly 'rest' enjoyed by God's people. If so, then the Christian's attitude to the physical Land must be one which downplays its significance. To be sure, Hebrews does not develop this at the time, reserving the full force of his argument concerning types and fulfilment until his discussion of the Temple; yet it can hardly be illegitimate to see how the pattern of his thinking, as revealed in those later chapters, would cause him to view the Land in the same way as he does the Temple. As the Temple is now eclipsed by the revelation of the 'heavenly sanctuary', so the Land is eclipsed by the new focus on the heavenly 'rest'.

Further indications of this can be discerned in ch. 11. In fact the whole of this chapter may possibly be making a point concerning the Land. Is it coincidental that Hebrews breaks off his detailed list of those who lived 'by faith' at precisely the point in the Old Testament story when the Israelites enter the Land (v. 31)? He then passes quickly through some of the key figures who were 'great' in the Land before concluding with those of whom 'the world was not worthy' (v. 38). This is all part of his argument that God's people may need to look beyond the present; yet it also implies a critique of any undue emphasis on the Land. For his list amply illustrates that faithful living does not depend on residence in the Land. His greatest examples of faith were those who practised it outside the Land.

The exception to this might be thought to be Abraham and his sons, who did live intermittently in the Land. Yet in his 
analysis of their faith (vv. 8-16) the author instead articulates precisely this ambivalent view of the promised land. He uses the actual phrase 'land of promise' (without further specification) in v. 9 and in the previous verse he has identified this as the 'place he would later receive as an inheritance'. These positive descriptions of the physical Land, however, are then immediately eclipsed by his insistence that the real focus of the promise to which Abraham 'looked forward' was the 'city with foundations whose architect and builder is God' (v. 10). This eschatological focus is then repeated in v. 16:

Instead, they were looking for a better country-a heavenly one. Therefore God is not ashamed to be called their God, for he has prepared a city for them.

The patriarchs, therefore, were looking forward, not so much to the day when their descendants would inherit the physical Land, as to the day when they would inherit the heavenly country (or city) which the physical Land signified.

In imputing such an attitude to the patriarchs the author once again has to draw implicitly on the assumptions of typology, whereby the promise concerning the Land, whilst real and valid in its own terms, must be seen as a pointer to something far greater. Moreover, it is this ability to see beyond present realities to their true heavenly fulfilment which is precisely one of the key hallmarks of the attitude of faith described in this chapter. Inevitably, therefore, if his readers were ever to manifest an enthusiastic attitude towards the contemporary Land, his response would have been decidedly negative: the whole essence of the faith which he was trying to encourage was one which looked beyond such things.

\section{b) The City of Jerusalem}

The above verses in 11:8-16 also serve to introduce Hebrews' readers for the first time to the question of the 'city'. It is significant that in both v. 10 and v. 16-verses which conclude paragraphs that were initially concerned with either the 'promised land' or the patriarch's 'country'/homeland ( $\pi \alpha \tau \operatorname{cis}$ )-Hebrews' final remarks, by contrast, concern the 'city'. The notion of the 'city' was evidently of some impor- 
tance. What indeed were the consequences for the city of the preceding discussion about the Temple (in chs. 7-10)?

The reference to Jerusalem is, of course, quite oblique at this stage. Yet it has been plausibly suggested that Hebrews' reference to the 'city with foundations' (11:10) should be seen as an allusion to Psalm 87:1-2:25

He has set his foundation on the holy mountain; the Lord loves the gates of Zion more than all the dwellings of Jacob.

If so, the earthly Zion or Jerusalem is not far from the author's thoughts. Moreover, there is an implicit re-evaluation of this Old Testament material: for in identifying the 'city with foundations' (v. 10) with the 'heavenly' one (v. 16) there is an implicit denial that the earthly Zion has truly divine foundations. The words of this psalm would therefore need to be seen either as a reflection of something which was true only temporarily but no longer, or (perhaps more likely?) as being always from the outset a reference to the 'heavenly Zion'. Either way the divine foundation of the earthly Zion/Jerusalem is thereby called radically into question.

In the next chapter the sermon, which has been based so much on the concept of the pilgrim journey of faith, now reaches its own $\tau \varepsilon \dot{\lambda}{ }_{0} \varsigma$ or climax with the colourful description of his audience's proleptic arrival in the heavenly city:

But you have come to Mount Zion and the city of the living God-the heavenly Jerusalem (12:22).

Though this passage is far from being a mere critique of the earthly Jerusalem, there are several implications concerning the city which need to be noted.

First, Hebrew's careful word order in this verse indicates that it is not just the cultic aspects of Jerusalem's Temple which have been 'relocated' in the heavenly Jerusalem. The antitype of the 'heavenly Jerusalem' is a two-fold entity which contains not just 'Mount Zion' (i.e. the Temple and its

${ }^{25}$ See esp. Moule, op. cit., 45; cf. Bruce, op. cit., 297, n. 85. 
cult) but also the 'city'. ${ }^{26}$ Both cultic and civic aspects of the earthly Jerusalem are seen now to be caught up within the definition of the heavenly Jerusalem. At the least this suggests that, whilst the greatest space in the argumentation concerning types had necessarily been given to the cult and the Temple, the author would not have been averse to a similar pattern being applied to the city. Both must now be understood as pointing beyond themselves to the greater, heavenly reality.

Secondly, Hebrews has significantly reworked the popular notion of pilgrimage. 'Pilgrimage' to a Jewish mind would have been inextricably linked as a concept to the city of Jerusalem; this alone was the goal of a Jewish pilgrim. ${ }^{27}$ In now portraying the Christian life as a journey to the heavenly Jerusalem, Hebrews has appropriated the powerful imagery of pilgrimage in such a way as to call into question the enduring validity of actual pilgrimage to Jerusalem. Such pilgrimage, he indicates, must be seen as but a picture of the only pilgrimage that ultimately counts; the focus of one's religious aspirations must no longer be the earthly Jerusalem, but the heavenly Jerusalem. Regardless of their geographical location and without any need to embark on a physical journey his audience truly have already 'come to Mount Zion' ${ }^{28}$ The journey to the

${ }^{26}$ This point is obscured in the NIV translation which inverts the order of the second and third elements ('you have come to Mount Zion, to the heavenly Jerusalem, the city of the living God').

${ }^{27}$ This inevitable Jerusalem-connection has not been sufficiently noted by those who have drawn attention to the dominance of the pilgrimage theme in Hebrews: see e.g. W.G. Johnsson, 'The pilgrimage motif in the book of Hebrews', JBL 97 (1978) 239-51.

${ }^{28}$ This spiritualizing tendency had already been developed in Diaspora Judaism: see e.g. H.A. Wolfson, Philo (Cambridge, MA: Harvard University Press, 1947) II, 241-8. Yet the evidence suggests that religious commitment to Jerusalem remained strong (Safrai, art. cit.). Hebrews' understanding of the Christian message effectively denied any sense of Jerusalem-dependency, thereby cutting the ties between the Diaspora and Jerusalem. Moreover, Hebrews' argument is substantially new when compared with any Jewish antecedents, not only because of its basis on the work of Christ, but also because he employs the category of the 'heavenly Jerusalem' as something which undercuts the earthly Jerusalem rather than as something which is integrally connected with it. Given his critique of involvement in Jewish meals which affirmed the Temple's 
heavenly Jerusalem does not go via the earthly Jerusalem. ${ }^{29}$ At one stroke, therefore, in creating a framework for the Christian life, Hebrews has undercut a key element in Jewish spirituality.

\section{c) Conclusion}

The above analysis suggests that, though the author has many other concerns as well, the theme of Jerusalem and the Land (and of his audience's proper approach to these essential parts of their Jewish heritage) is never far from his mind. The three concentric realia of Judaism are each dealt with in turn: the Land (chs. 3-4), the Temple (chs. 5-10), and finally the city (chs. 11-13). In some ways this order reflects the pivotal centrality of the Temple; yet the fact that the city is only addressed in the final, climactic sections also reveals the powerful eschatological and political symbolism of Jerusalem the city-symbolism that needed to be addressed if a new Christian vision of the future was to be forged in contrast to that offered within Judaism.

The suggestive ideas sown within the course of the sermon concerning the 'city' thus come to fruition in 13:9-14 and prepare the audience to hear in these verses an application to the earthly city of Jerusalem for which otherwise they might have been unprepared. Admittedly in 13:12 there is a new idea (that Jesus' crucifixion calls into question Jerusalem's holiness) but this is surrounded by statements that merely repeat what has been substantiated earlier: the relocation of the true 'altar' and Temple (vv. 10-11) and the existence of the 'city that is to come' (v. 14). These statements, together with those concerning the Land in chapters 3-4 and 11, indicate quite sufficiently that for the author Jerusalem's religious significance is a part of the 'old order' which will 'soon disappear' (8:13).

In 13:9-14 Hebrews thus makes practical applications of his earlier argumentation, both with respect to his main theme (his audience's involvement with Jewish meals and their need to break with that aspect of their Jewish heritage) and with respect to this sub-theme of Jerusalem. Yet, if this reading is correct, then the implied critique of Jerusalem's status proves

validity, he would be most unlikely to endorse Jewish pilgrimage to Jerusalem and its Temple.

${ }^{29}$ See above I (c). 
inevitably to be more integral to his main theme. For to espouse such a negative attitude towards Jerusalem is very much to make a radical break with that Jewish heritage and in a way that inevitably (more so than with respect to the Temple) has repercussions of a distinctly 'political' nature.

Moreover, the author is aware that this call is not only radical but costly; the new pattern of worship revealed through Jesus will never have a city which will serve the same religious function as had Jerusalem for Jews. In all other matters, whilst apparently impoverished when compared with their fellowJews, Christians are actually the richer. As Chris Wright says:

Hebrews' affirmations of what 'we have' are surprisingly comprehensive. We have the land, described as the 'rest' into which we have entered through Christ, in a way which even Joshua did not achieve for Israel (3:12-4:11); we have a High Priest (4:14, 8:1, 10:21) and an altar (13:10); we enter into the Holy Place, so we have the reality of tabernacle and temple (10:19). We have come to Mt. Zion (12:22) and we are receiving a kingdom, in line with Haggai 2:6 (12:28). Indeed, according to Hebrews (13:14), the only thing which we do not have is an earthly, territorial city! 30

The author generally pursued a strategy of encouragement, but on this issue of Jerusalem there was a definite and inevitable challenge. Although they can look forward to the 'heavenly Jerusalem', for now they must forego their attachment to the earthly city: 'for here we do not have an enduring city, but we are looking for the city that is to come' (13:14).

\section{Implications for dating}

This critique of the land and of Jerusalem has been noted in a recent work on Hebrews by Marie Isaacs entitled Sacred Space. ${ }^{31}$ She writes that 'our author inherited notions of sacred space

${ }^{30}$ C.J.H. Wright, 'A Christian approach to Old Testament Prophecy concerning Israel', in Walker, op. cit., 18-19; cf. Dunn, op. cit., 86-91.

31M.E. Isaacs, Sacred Space: An Approach to the Theology of the Epistle to the Hebrews (JSNT Supp. 73; Sheffield: Sheffield Academic Press, 1992). 
whereby it was identified with the land, Jerusalem, Zion and the sanctuary' 32 and argues convincingly that the author's purpose is to 'relocate' these in 'heaven'. 33 Yet she concludes that such an emphasis and such a re-working of Jewish concepts must have been occasioned by the Fall of Jerusalem in AD 70:

A sense of loss, inevitably felt keenly by Jewish Christians, called forth from our author a reinterpretation of Judaism's established means of access to God...It is the displacement felt by his addressees as a result of the actual loss of Jerusalem which seems to give rise to his need to present Jesus as making the necessity for such a place redundant. Hence, Jesus is shown to have gained access to the only sacred space worth having-heaven. That space is superior to any previously gained through entry into the promised land or into the inner sanctum of the cult place. Trusting in this, his readers should not hanker after the lost Jerusalem. ${ }^{34}$

In some ways this is a natural conclusion to draw. When Hebrews' radical re-working of the traditional Jewish concepts has been truly recognised it is tempting to suggest that only the radical upheaval of $\mathrm{AD} 70$ could have prompted such forthright revisionism. Yet, as shall now be indicated, there is good evidence for arguing that Hebrews was written before 70 .

As noted at the outset, numerous scholars have argued for such an early date. ${ }^{35}$ The reasons offered for this normally include the following:

32 Op. cit., 62.

${ }^{33} \mathrm{Op}$. cit., 219.

${ }^{34}$ Op. cit., 67; cf. also ibid., 44.

${ }^{35}$ See above $n$. 1 . Such scholars contend that the reference to the 'former days' (10:32) does not necessarily speak of a vast span of time and the fact that his readers had not first heard the Gospel from 'the Lord' but 'from those who heard him' (2:3) does not indicate that they were 'secondgeneration Christians' in the normal sense of that term; see Hughes, op. cit., 30: 'their conversion could have taken place any time after Pentecost'. The 'yesterday' of 13:8 refers to the time of their conversion, not to the date of the death (or martyrdom) of their first leaders: contra R.E. Brown and J.P. Meier, Antioch and Rome (London: Cassells, 1983) 149. 
i) The clear allusion to Hebrews $1: 1-3$ in 1 Clement (36), normally dated to c. 96AD;

ii) The use of the present tense concerning the Temple ritual (especially in 9:6-9), and the absence of any reference to the destruction of the Temple which would have been major supportive evidence for the validity of his argument;

iii) For those who suggest a Roman destination of the Epistle, the reference in 12:4 to the fact that the readers had 'not yet resisted to the point of shedding their blood' (if taken literally) may suggest a date prior to Nero's persecution (AD 64-67), while the reference in 10:32-4 to their 'suffering' in 'earlier days' may reflect the Claudian edict against Roman Jews in AD 49.36

Given the uncertainty of the Roman destination, the single most important clue for dating is evidently this issue of the Jerusalem Temple: was it still standing when Hebrews was written? Advocates of an early date point to the use of the present tense and ask, 'If the Temple had recently been destroyed, could Hebrews have failed to refer to this event which so clearly vindicated his argument?' Advocates of a later date, by contrast, must see the use of the present tenses as a literary device and ask, 'Could such a critique of the Temple have been formulated before its destruction?' In many cases it is this latter theological assumption (that Hebrews could not have been so negative about the Temple whilst it was still operational) that appears determinative. Yet what is the basis for this assumption?

The convincing arguments for interpreting Hebrews' consistent use of the present tense at their face value will not be rehearsed here. ${ }^{37}$ Our task is simply to draw attention to other factors which support this straightforward interpretation.

\footnotetext{
${ }^{36}$ See e.g. Lane, op. cit.; Bruce, op. cit.; W. Manson, The Epistle to the Hebrews (London: Hodder \& Stoughton, 1951); Brown and Meier, op. cit., 142-9. For alternative destinations, see further below n. 52 .

37See esp. Hughes, op. cit., 30-32, who lists the 18 passages where Hebrews uses a present tense. Advocates of a later date refer to passages such as 1 Clement (40:4-5) and Josephus, Against Apion (2.77) to show that a present tense could still be used of the Temple ritual after AD 70. Yet these writers (unlike Hebrews) were not arguing for the theological redundancy of the Temple; it is this factor which makes Hebrews' use of the present tense so
} 


\section{a) 'Disgrace' in the eyes of Judaism}

First, what was it that was making the audience tempted to 'shrink back' (10:39)? Throughout his final chapters the author was encouraging his listeners to a renewed confidence in the face of adversity (e.g. 10:32-39) and a renewed 'faith' (ch. 11). Why were they fearful?

The most clear indication again comes in Hebrews 13:914 with its challenge to 'go to [Jesus] outside the camp, bearing the disgrace he bore' (v. 13). Though this is hard, the author is calling them to share in the 'disgrace' that Jesus experienced in himself being cast 'outside the camp'. This challenge has subsidiary applications in any age to Christians to share in the 'sufferings of Christ' and to face hostility from whatever quarter, yet the primary reference in its original context must surely have been to the feared hostility of those within the 'camp' of Judaism. For the power of Hebrews' picture lies precisely in the fact that he sees the closest of parallels between what Jesus suffered and what his readers may suffer in the near future. The 'disgrace' which they feared was that which they expected to receive from their fellow-Jews. ${ }^{38}$

In principle this need not be determinative for dating; yet we suggest it favours a date before AD 70 for two reasons. First, the recipients' fear of incurring disgrace in the eyes of Judaism would be far less reasonable after 70 when Judaism had itself been significantly 'disgraced' and lost some of its coercive power. Secondly, if as suggested here a major cause of the feared disgrace was the recipients' negative attitude to the Temple, the outrageous nature of this opinion would have been

significant. Nor can Hebrews' silence concerning AD 70 be explained by saying that to do so would have tied his argument to a merely temporal (and potentially reversible) phenomenon; a reference to it would have acted as a confirmation of his argument without altering the fact that his critique was ultimately based on the work of Christ alone.

${ }^{38}$ This will be disputed by those who wish to minimize the evidence of Jewish hostility to Christians in the first century, yet there is no evidence of any Gentile persecution before Nero. It also calls into question those interpretations (such as in Lane and W. Manson) that see Hebrews' recipients as being chiefly afraid of the secular Roman authorities and thus tempted to seek asylum in a Judaism which possessed the status of a religio licita. 
somewhat ameliorated after 70 when Judaism itself was forced to develop a similar (though radically different) spiritualising attitude towards the role of the Temple.

\section{b) Tempted, not bereft}

Secondly, contrary to Isaacs (above), the impression we gain of Hebrews' recipients is not that they are bereaved, but that they are tempted. None of the many passages which gives us an insight into their frame of mind indicate that they are feeling lost or bereft of the Temple. On the contrary, the author is constantly warning them of the dangers of 'temptation' (especially in chs. 3-4). Although he continuously applies a balancing amount of encouragement and challenge, the predominant note is one of warning not to succumb to temptation.

Such language makes far more sense if the Jewish alternative, based on the Temple, was a viable and established system; it is hard to see how a post-70 Judaism would have presented Hebrews' audience with such an alluring and hardto-resist temptation. They were tempted by a Temple system that was very much operational and still powerful.

\section{c) Hebrews' great care}

Thirdly, there is ample evidence of the enormous care that the author took to convey his message. ${ }^{39}$ This again is more likely to reflect a pre-70 date when with the looming clash between Jerusalem and Rome there would have been great sensitivities about the Temple and when such negative views as Hebrews espouses would indeed have been seen as almost treacherouscertainly placing him 'outside the camp'.

This need for careful wording may explain his consistent (and otherwise puzzling) use of 'tabernacle' ( $\sigma \kappa \eta v \hat{\text { ) }}$ ) when referring to the Temple. We must resist the temptation to see this as a mark of the author's concerns being rather 'academic'

${ }^{39}$ This is discussed most recently by Lindars (op. cit., 7, 11, 15) who notes the author's anxiety as to how his letter will be received, his fear that they will indeed reject his message and his consequent need to establish as much rapport with them as possible. 
and unrelated to contemporary Jerusalem. 40 On the contrary, it is precisely because he is saying such radical things about the Temple and Jerusalem that he needs to use this strategic device.

Hebrews 13:9-14 again makes this clear. In these verses, which are dealing with the practical applications of the argument, the reference to 'those who minister at the tabernacle' ( $\mathrm{v}$. 10) can no longer be interpreted in purely theoretical terms but must refer to those involved (directly or indirectly) with the worship of the Temple. If not clear previously, it is now revealed that all of his discussion about the 'tabernacle' does indeed have a contemporary referent and has unavoidable repercussions for a Christian approach to Jerusalem's Temple.

If, as we contend, this issue of the Temple's continuing significance was what underlay the recipients' involvement in Jewish meals and occasioned the whole letter, then the author's care is to be expected. For if he made any negative remark about the contemporary Temple before he had established his case for the High Priesthood of Jesus, he might well have lost his audience. Hence the argument needed to be kept at an apparently theoretical level for as long as possible.

Moreover this suited his theological purpose. For he was decidedly not trying to argue simply against contemporary Judaism and some of its less creditable manifestations; such critique was not uncommon in the Judaism of the period. 41 His critique was much more fundamental. It was for this reason that he focused on the Israel of the wilderness era, for by showing Christ's fulfilment of that he effectively undermined Judaism at its source. This was a criticism that went to the root and was not overly concerned with peripheral matters. 42 Avoiding references to contemporary first-century Judaism was thus an obvious necessity from a theological point of view; for

${ }^{40}$ E.g. P. Ellingworth, The Epistle to the Hebrews (London: Epworth, 1991) viii: 'the writer shows no interest in what was going on in Jerusalem at the time he wrote'; R.M. Wilson, op. cit.: 'he shows no interest in contemporary history'.

${ }^{41}$ For the attitude to the Temple of the Qumran community see B. Gärtner, The Temple and the Community in Qumran and the New Testament (Cambridge: CUP, 1965).

${ }^{42} \mathrm{Cf}$. Dunn, op. cit., 87: 'it was the very principle of a special cult... which the author wished to contest'. 
else his criticism would have appeared not as revolutionary but as merely reforming. Yet it also ensured that he did not get embroiled in contentious semi-political issues and thus avoided giving undue offence to anyone who might read his sermon.

This suggests that the letter was written at a time when such a radical message had to be conveyed with great tact and caution. Whilst the issue of the Temple would continue to have been a focus of dissent after 70 it is far more likely that the years before 70 provide the context for the author's evident concern.

\section{d) Sense of expectancy}

Fourthly, Hebrews brims with a sense of imminence and expectancy. Much of this must be explained by its eschatological emphasis and its portrayal of the Christian life as a pilgrimage upwards to a heavenly goal. 43 Yet some of this could have been influenced by a belief that there would soon be an 'act of God' which would affect Jerusalem.

Both Bruce and Guthrie, for instance, draw attention to the references in 3:9 and 3:17 to the 'forty years' in the wilderness and suggest that, though Hebrews' use of Psalm 95 necessarily introduced this terminology, there may have been an extra reason for his use of this psalm if indeed the fortieth year since Jesus' crucifixion was approaching. ${ }^{44}$ Drawing upon four parallel references in the Qumran literature, Bruce writes: 45

We have evidence of a belief that God's dealings with Israel, which began with a probationary period of forty years, would be rounded off at the end-time by a probationary period of like duration; and (if this epistle was written shortly before $A D$ 70), it was nearly forty years now since Jesus had

43See esp. C.K. Barrett, 'The Eschatology of the Epistle to the Hebrews', in W.D. Davies and D. Daube (eds.), The Background of the New Testament and its Eschatology (Cambridge: CUP, 1956) 363-93.

${ }^{44}$ Bruce, op. cit., xliv, 65; Guthrie, op. cit., 29; cf. Spicq, op. cit., 261.

${ }^{45} \mathrm{CD}$ 20:14f. (forty years between the death of the Teacher of Righteousness and the 'consuming of all the men of war who returned with the Man of Falsehood'); 4QpPs. 37, frag. A, 1. 6ff. (the forty years after which the wicked are no more); 1 QM passim (forty years' warfare); and TB Sanhedrin 99a (the days of the Messiah will be forty years). 
accomplished his 'exodus' at Jerusalem. Hence the urgency of the present appeal to the readers to take heed 'so long as it is called Today'. 46

If correct, many aspects of Hebrews become clearer. The quotation of Psalm 95 is now seen to play a strategic role near the outset of the sermon for explaining the comparative urgency of the times. More importantly this may suggest that the author understood the 'last days' (1:1) in a particularly urgent way; he was looking to a further 'act of God' in the imminent future which would endorse (or even conclude) God's purposes in Christ. Hence his urgency.

One striking corroboration of this comes in 8:13, where in expounding Jeremiah's prophecy of the 'new covenant' he describes the first covenant as 'obsolete' and then concludes:

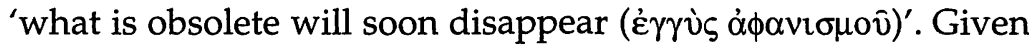
the whole thrust of the argument in this section, which sees the old covenant as focused particularly in the sacrificial ritual of the 'tabernacle', the 'disappearance' of the old covenant must involve the end of the Temple-the contemporary locus of that tabernacle ritual. The author's use of 'covenant' rather than Temple terminology is a further example of his 'political' sensitivity, yet his meaning is plain. He is so convinced of the reality of the 'new covenant' inaugurated in Christ that, despite the outward continuance of the ritual associated with the 'old covenant', he dares to proclaim-with a prophetic spirit not so different from that of the Jeremiah he has just quoted-that the

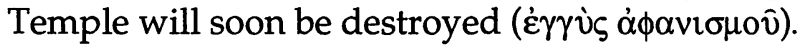

Hebrews was thus working on the assumption that something significant would soon take place in Jerusalem. Tom Wright has argued that this assumption may have been far more widespread in the first apostolic generation than has previously been allowed and that it is this which lies behind some texts which are often interpreted as referring to the Second Coming. For example, commenting on 2 Thessalonians 2:2 (Paul warning his readers not to believe false reports that the 'day of the Lord has already come'), Wright says:

46Bruce, op. cit., 65. 
If Paul meant by 'the day of the Lord' the end of the spacetime universe, the Thessalonians would presumably not need to be informed of the fact via the Roman postal service! Instead, Paul here reflects the early Christian tradition, going back to Jesus himself, according to which Jerusalem was to be destroyed, and according to which that destruction was to be interpreted as the wrath of God against his sinful people. In the same Thessalonian correspondence, Paul asserted that the wrath of God had indeed come upon them 'to the uttermost'

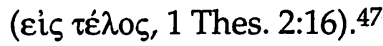

If so, several passages in Hebrews may now be seen in a new light. For example, does this conviction about Jerusalem underlie his wording in both 10:25 ('all the more as you see the Day approaching') ${ }^{48}$ and 10:37 ('for in just a very little while "he who is coming will come and not delay"')? ${ }^{49}$ It may also be part of what he means when he warns his listeners about the 'removing of what can be shaken' (12:26-27).

In each of these instances the wider reference (to an event more universal in scope) cannot be denied, but the more specific application to Jerusalem may need to be acknowledged as well. Living prior to the event the author would have been unable to distinguish between the particular and the universal, between the destruction of the Temple and the Return of Christ: would they be integrally connected, or would they be quite separate? The language of Hebrews, however, indicates that it was written in this period before 70 when, fuelled by a conviction that the Temple would soon to be destroyed, the author wrote with a sense of profound urgency-an urgency born of not knowing if this dramatic event in Jerusalem would signal the 'coming' of Jesus or not.

Such an understanding of the author's vision for the future not only adds to the likelihood of his writing before AD 70; it also augments our contention that the Jerusalem theme is close to the heart of his concerns. For if the Temple is to be destroyed, that will inevitably have repercussions for the city of

47N.T. Wright, 'Jerusalem in the New Testament', in Walker, op. cit., 64.

48 On this verse, see further below IV (a).

${ }^{49}$ This interpretation of Heb. 10:37 is followed by K.L Gentry in Before Jerusalem fell: Dating the Book of Revelation (Texas: Tyler, 1989). 
Jerusalem and for the whole religious polity of Judaism. It may also explain why the author was taking such a radical view of the need for Jesus' followers to make a break with their Jewish heritage: for 'Jerusalem' was on this reckoning by no means the haven of safety that they presumed it to be. 50

\section{e) The call to 'faith'}

A final suggestive indication that Hebrews was written before AD 70 is found in the emphasis on the need for faith (seen especially in ch. 11). When faith is defined as 'being sure of what we hope for and certain of what we do not see' (11:1) the primary reference may well be the need for Christians to focus their spiritual sights on the unseen realities of 'heaven'. Yet again there may be a secondary resonance relating to the author's convictions about Jerusalem and the Temple. For both Hebrews' own critique of the Temple and the challenge to 'leave the camp' required precisely this kind of faith that looked beyond the present to God's unseen future.

After AD 70, when the Temple had been destroyed and Judaism severely weakened, such a view and such a challenge would have been far easier to make and have required far less faith; they might even have appeared somewhat obvious, for there was now visible circumstantial evidence to support this position. It was much harder, however, to take this line before AD 70 when the Temple stood in all its glory. If Hebrews was written before 70 , then to say what it says required real faith; and to heed the challenge required faith-faith in a God who could do what as yet 'we do not see'. Moreover, it required faith in the great significance of Jesus-that through his act of dying on the Cross in weakness the entire Temple system could be fulfilled and outmoded. No wonder he called his fellow Jewish-Christians to a renewed faith.

For all these reasons, the text of Hebrews forces us to concede the real possibility that it dates from before AD 70 . Had it been written after that date, the author's challenge concerning Jerusalem would have been less 'disgraceful'; it

\footnotetext{
50See below IV (a). This gives a new perspective on the common argument concerning Judaism as the religio licita (see above n. 38); the author is urging that it is not necessarily the safe place that it might appear.
} 
would have required less faith, demanded less courage and indeed been in itself less necessary-for his challenge to 'leave the camp' depends for its force on the 'camp' of Jerusalem being a powerful entity that is difficult to leave. In conclusion, some implications of such a conclusion need to be addressed.

\section{Biblical and Theological Consequences}

\section{a) Understanding the listeners' context}

The above discussion suggests that we should date Hebrews to some time before $\mathrm{AD} 70$. It is impossible to be more precise than that-though a date before AD 60 would seem unlikely.

The Jewish revolt (which broke out in AD 66) is not mentioned in the text, but this cannot rule out the possibility that Hebrews is written during those crucial years. Indeed the tension of those years would not only explain Hebrews' great care in keeping his argument at the strictly theological level (for his anti-Zealot views would be particularly unwelcome at that time); it would also explain his sense of imminence and urgency-for this would then be a reflection in theological terms of the increased tension surrounding Jerusalem politically. Alternatively Hebrews may have been writing before the war; in which case his arguments will have been more theologically motivated, though perhaps with an element of political insight, being aware that the coming years would be crucial for the relationship between Jews and Christians.

In either case, we suggest that part of the reason why Hebrews' readers were being strongly tempted to identify more visibly with their Jewish fellow-nationals was precisely because this was an era of increased tension within Judaism. In such circumstances their fellow Jews might well have felt quite keenly that this was a time for all Jews to show solidarity and to affirm the centrality of the Temple within their religious and political identity. The question of whether or not JewishChristians attended a Jewish festival meal (or some other ceremony that drew its significance from its link to the Temple cult) would then become quite significant; for their absence 
could be interpreted as an act of great disloyalty, and as a refusal to show political solidarity with the Jewish cause. 51

Such a context may throw some new light on an intriguing verse (10:25):

Let us not give up meeting together, as some are in the habit of doing, but let us encourage one another-and all the more as you see the Day approaching.

As suggested above, the 'Day' to which Hebrews refers here may not be the 'parousia' as such but rather the 'coming' of the Lord in judgement upon Jerusalem. If so, this would make more sense of the verse for two reasons. First, his language ('as you see the Day approaching') suggests that at the time of writing there were some observable and visible signs which could be taken as pointing to some such dramatic denouement; if they were aware of the increasing tension between Jerusalem and Rome (perhaps even with Roman forces beginning to mass against the city) then this is easily explained.

Secondly, the logic of Hebrews' argument becomes much tighter. For if Christian Jews were being pressurized by non-Christian Jews to show visible signs of solidarity with the nation of Israel by attending Jewish ceremonies, inevitably 'some' would become reluctant to 'meet together' as Christians; for at this critical time they were under pressure to give a greater loyalty to their Jewish relationships and traditions than to this novel Messianic sect. The logic of Hebrews' argument is then as follows: though this is indeed a critical time and one where they will understandably experience much pressure from their Jewish fellow-nationals, yet in fact this is that Day indicated by Jesus as spelling the judgement on Jerusalem; contrary to appearances, therefore, this is precisely the time to be siding not with the Jewish people but with the people of

${ }^{51}$ Lindars, op. cit., 12-14 suggests that the audience's involvement in these meals was due to their religious need for practical tokens of atonement. This political context, however, suggests they were not motivated primarily by such religious convictions, but rather by factors more political and social. This would then explain why Hebrews implies that their action does not betray deliberate and conscious apostasy; rather it is unwittingly moving in that direction. 
Jesus. As they 'see the Day approaching' that is good reason not for abandoning Christian fellowship but rather for meeting with fellow Christians 'all the more'.

Such an interpretation provides a convincing context within which to understand Hebrews. Hebrews' conscious and careful emphasis on theology has caused interpreters to miss the 'political' context and to assume that its readers were troubled by some 'spiritual' problem. More probably, however, they were succumbing to a pressure which in the first instance presented itself as more 'social' but which the author had to demonstrate was inherently religious as well. This explains how the author can be fearful of their apostasising and yet be confident that this is not what deep down they want to do. For their compromised position is one which they have embarked upon not for reasons of theology but for reasons of social convenience. It is his delicate task then to show them that their position does involve a theological compromise which is unacceptable. Involvement with Jewish festival meals may seem a small thing and natural enough, but in fact it involves their endorsing a whole system which is defunct and which God is soon to bring to an end. Despite the pressure they are under and the 'disgrace' they will incur, they are to have 'faith' in God as Jesus did 'holding firmly their confidence to the end' (4:14).52

52In comparison with the issue of dating, the question of the destination of the epistle is less material, as well as being harder to specify. Much depends on 13:24 ('those from Italy send their greetings'): is he writing from Italy or to Italy? Our thesis would support any destination within the Diaspora: for even in absentia the question of Jerusalem's significance would have been a vital Jewish concern. Some scholars noting this Jerusalem-theme have concluded that the recipients may be residents in or near Palestine (Spicq, Hughes and Isaacs) or even in Jerusalem itself (Buchanan and all those in the long list given by Spicq: op. cit., I, 239, n. 1). If they were, there would then be an extra poignancy in Hebrews' description of Abraham as an 'alien in the promised land' (11:9), for this might describe neatly their experience of hostility from their fellow countrymen. Moreover, their fear of 'disgrace' in Jewish eyes might be more legitimate in the very homeland of the Jews-especially as the issue of patriotic loyalty came to the fore in the years before 70 . Yet, even if this is not the case, there may still be some justification for saying that the author himself must at least have had some experience in situ of the issues of Jerusalem, Land and Temple. Cf. above n. 36. 
b) The early critique of the Temple and Jerusalem

If Hebrews is dated before AD 70, then it also follows that no longer can its negative attitude towards the Temple be interpreted simply as a post-eventum rationalisation of the Fall of Jerusalem. The above presentation denies this and forces us to seek an alternative explanation for his attitude. His approach to the Temple is not parallel to and contemporaneous with Jewish 'spiritualising' after 70; on the contrary, it is both earlier and founded on a prior event.

Moreover, if true, this forces us to re-examine the posteventum assumption in other areas of New Testament study. For example the speech of Stephen (Acts 7) and especially the judgement-predictions attributed to Jesus in the Gospels are often thought to have been influenced by the later and more negative attitude of the writer. The picture is thereby given that the earliest Church was in the main positive about Jerusalem and the Temple, and that it was only the events of AD 70 that forced them to a new stance.

Yet the involvement in Acts 2-4 and 21 of the Jerusalem church in the life of the Temple (which is often used to defend this 'positive' position) may not necessarily bear this interpretation. Rather than being the norm, this involvement of the Jerusalem church may have been the exception, and that the prevalent Christian view of Jerusalem and the Temple was more negative. This would make for much greater continuity between the recorded teaching of Jesus on the subject and the attitude of the early church. The positive attempts of the Jerusalem Christians to be involved with the Temple would then be seen as reflecting the natural desire that Jesus' prophetic words against Jerusalem and the Temple should not come to pass-a desire which increasingly was thwarted, leaving space for the negative theme to re-surface. It could not be said that they had not tried.

Hebrews' attitude would then be part of this re-surfacing of the negative approach. This would in turn neatly explain the paradox that the author of Hebrews appears to be saying something which he believed to be both old and new, both integral to the original Gospel and yet now vitally urgent in a new way. For this is only to be expected if Jesus had 
pronounced judgement upon Jerusalem and the Temple (thus making this part of the original message) but that only now, after a period of hoping this judgement would pass, had it become clear that it certainly would not. It was the original message but with a profoundly new relevance.

Paul's scathing comments about 'the present city of Jerusalem' being 'in slavery with her children' (Gal. 4:25) _even if fuelled by some painful experience at the hands of those in Jerusalem (both Jew and Christian)-nevertheless come in probably the earliest New Testament letter and indicate that such negative attitudes to Jerusalem could easily be voiced by Jewish-Christians well before AD 70. On this score, there is no great distance between Paul's position in Galatians and the book of Hebrews: why then the need to date Hebrews to the years after AD 70?

The assumption that Hebrews cannot have been written before 70 probably reflects several deep-rooted convictions held for quite other reasons. For example, our thesis endorses the possibility of predictive prophecy in the teaching of Jesus concerning Jerusalem. Secondly, it raises the necessity of attempting to interpret $\mathrm{AD} 70$ in theological terms; for though the author of Hebrews is careful himself not to speak in terms of judgement upon the city, the Jesus portrayed in the Gospels certainly did. Thirdly, it involves the acceptance that the negative attitude towards Jerusalem and the Temple may go back to Jesus himself and in any event was prevalent before $\mathrm{AD} 70$; this negative stance cannot therefore be dismissed as merely reactive but has to be acknowledged as more truly part of the essential message of the early Christian church. Finally, it involves a more pessimistic view of the relations between Jews and Christians in that first generation than perhaps we would prefer.

In our day the possibility of predictive prophecy, the notion of divine judgement and the inherent dichotomy between Judaism and Christianity are all keenly disputed; it is not therefore surprising that Hebrews is often placed safely after $\mathrm{AD} 70$. Yet we suggest this cannot be done. If so, then there are strong grounds for challenging these theological assumptions. 


\section{c) The prophetic nature of Hebrews}

Finally, the author's vision of what was to befall Jerusalem and the Temple and his warnings to 'go outside the camp' give his words a prophetic quality. Just as Jeremiah had been sent to warn God's people of the imminent fall of Jerusalem in 587 BC, so now this anonymous author spoke urgently to those tempted to return to (or remain within) 'the camp'. This conviction about the future might be but a realistic assessment of the likely outcome of contemporary events in Judaea, but could also have been fuelled by reflection on the warnings of Jesus as recorded in the Gospels.

When in the following verse (13:14) he concludes his appeal by stating that 'here we do not have an enduring city', we should therefore be open to the note of prophetic warning that rings through these words. This is no bland statement concerning the transitoriness of life in general, but a solemn and specific warning. Though he has his eye on something more than just the physical city of Jerusalem, his words are yet not that dissimilar from those on the lips of Jesus in Luke's Apocalyptic Discourse:

Then let those who are in Judea flee to the mountains, let those in the city get out, and let those in the country not enter the city (Luke 21:21).

The historical and literary connection between Hebrews and Luke in this matter cannot here be pursued, but the parallel is suggestive. The author of Hebrews is saying something essentially similar-though, inasmuch as he was probably speaking to those who did not physically live in Jerusalem, he has broadened the reference to the 'camp' of Judaism as a whole. Yet in widening the application the truth of what lies in store for the actual city of Jerusalem is far from lost. It is a warning to both Jews and Christians not to place their securities in Jerusalem.

The author of Hebrews is thus revealed as more than just an erudite and original teacher, more than just a skilful preacher and sensitive pastor. He also has a prophetic word for his day. He thereby modelled the very attitude of faith which he so much commended-the faith that does not see but believes in him who promised. 